\title{
Editorial
}

\section{Rbem: 20 anos de um Projeto de Consolidação de um Campo Acadêmico e Científico}

Sergio $\operatorname{Rego} o^{I}$

Este editorial é o último que redijo como editor-geral da Revista Brasileira de Educação Médica. Assumi esta honrosa função pela primeira vez em 1989, quando, sob a presidência do professor Frederico Simões Barbosa, fui designado diretor-executivo da Abem. Permaneci na função até que a então diretoria eleita, presidida pelo professor Benedictus Philadelpho de Siqueira, tomasse posse, em fins de 1990.

Na ocasião, vivíamos tempos muito difíceis. O mandato do professor Frederico foi atingido em cheio pelo malfadado Plano Collor, quando, numa virada de noite, todos os recursos financeiros da Associação foram bloqueados nos bancos. Na época, publicávamos o Boletim da Abem e a Rbem. Para ambos precisávamos de dinheiro, mas para a Revista havia também grande carência de artigos. Nosso sistema de submissão era manual e baseado nos Correios, o que também implicava consumo de recursos financeiros além do razoável, especialmente quando a Abem não dispunha deles, já que haviam sido bloqueados. Também não recebíamos muitos artigos e, portanto, tínhamos grande dificuldade em dispor de artigos suficientes para editar um número - na época, publicávamos três por ano. Saí da diretoria executiva com o início do projeto Cinaem, e as atividades da Associação ficaram bastante focadas na elaboração de uma proposta de avaliação e em sua execução, sem que fossem abandonadas as tarefas de publicar a Revista e o Boletim, e desenvolver os trabalhos do projeto Cinaem.

Retornei para a editoria-geral da Revista em 1998, convidado pela professora Jadete Lampert, na época diretora-executiva. Elaboramos um projeto de veículo de divulgação científica no qual o caráter acadêmico fosse central e o rigor necessário nos procedimentos de avaliação de artigos e publicação fosse absoluto e parte essencial do projeto de valorização da Revista. Sob a presidência da professora Regina Stella, implementamos esse projeto com total autonomia e transparência. Esse compromisso foi acolhido por todos os presidentes da Abem, que entendiam que um veículo de divulgação científica, para ser respeitado, deveria ter autonomia, embora não fosse independente, posto que a diretoria da Abem sempre participou da discussão das estratégias e das decisões centrais para o funcionamento da Revista, pois se tratava do órgão científico oficial da Associação.

A luta pelo reconhecimento do trabalho desenvolvido foi árdua: nos associamos à Associação Brasileira de Editores Científicos (Abec) e à World Association of Medical Editors; participamos de cursos de formação oferecidos pela Abec; submetemos vários projetos de apoio para a publicação ao CNPq e à Capes, tendo sido agraciados com grants em diversas ocasiões; tentamos várias vezes incluir a Revista na indexação da SciELO e aprendemos, a cada parecer negativo, como melhorar, até que finalmente fomos aceitos. Criamos neste processo a nossa página na internet e passamos a realizar as submissões e avaliações dos artigos on line. 
Entrar na base da SciELO sempre foi compreendido por nós como fundamental para a consolidação da Revista. Indexados à SciELO, passaríamos a contar com a submissão de artigos de docentes e investigadores vinculados aos programas de pós-graduação, já que, para a avaliação de seus desempenhos pela Capes, a qualidade dos periódicos onde eles publicam é fundamental. Não ocorreu de outra forma. A inclusão na base SciELO promoveu uma verdadeira explosão na submissão de artigos e, consequentemente, na aprovação (e também nas recusas, é claro). A primeira consequência deste boom foi a necessidade de atuar para tentar diminuir o tempo entre a aprovação de um artigo e sua publicação: passamos, assim, a ser uma publicação trimestral.

É claro que por trás desse enorme desenvolvimento da Revista e de seu reconhecimento estavam o apoio e a dedicação decisivos das diversas diretorias, como também a indispensável seriedade e rigor de toda a nossa equipe de consultores e avaliadores ad hoc. Os editores associados, cargos criados para dar um indispensável apoio ao editor-geral no cumprimento de sua missão, foram sempre estratégicos para aumentar a capacidade analítica técnica e ética do trabalho de avaliação dos artigos submetidos.

Mais do que editar e publicar uma Revista, tivemos sempre um projeto de desenvolvimento da área de conhecimento da Educação Médica. Os editores da Revista e as diversas diretorias com as quais tive o privilégio de interagir e cooperar tiveram sempre este objetivo a mais. Por esta razão, criamos o chamado Prêmio Abem de Educação Médica, em diversas categorias, procurando estimular docentes, discentes, residentes, mestrandos e doutorandos a apresentar seus trabalhos numa competição acadêmica cuja premiação era a publicação na Revista. Passamos a divulgar os anais dos congressos como números especiais não indexados, o que asseguraria sua presença na internet e a consequente ampliação da divulgação dos trabalhos apresentados.

Criamos também diversas chamadas especiais de artigos e as publicamos em alguns números especiais da Rbem, em geral como suplementos, o que nos possibilitou aumentar as interfaces com os serviços e aprofundar diferentes temas deste campo do conhecimento.

Nossa métrica atual demonstra esse sucesso: de acordo com o Google Scholar, somos a 39ª revista em português com o melhor índice H para cinco anos (16, com uma mediana de 22).
Desde dezembro de 2006, tivemos quase 2 milhões de acessos a artigos publicados em nossa revista através da SciELO, para um total de 635 artigos disponíveis.

Os desafios para a Rbem não diminuem, pelo contrário. As restrições financeiras para a publicação ainda impedem que ofereçamos o acesso à Revista em língua inglesa, o que representa um dos maiores desafios. Outros são: modernizar o sistema de submissão - o que em breve será alcançado com a migração para o sistema Scholar One, pela SciELO; disponibilizar os artigos na forma ahead of print, ou seja, permitir que sejam citados antes da publicação efetiva; investir no aumento de nosso índice de imediatez, ou seja, a frequência com que um artigo é citado no mesmo ano da publicação, bem como nossos índices $\mathrm{H}$ e fatores de impacto.

A ampliação e a renovação do corpo de revisores científicos da Revista já foram iniciadas pela nova editora-geral (professora Lilian Koifman), o que deverá ajudar a diminuir o prazo entre a submissão e o primeiro parecer disponível para os autores. A professora Lilian Koifman, da Universidade Federal Fluminense, que assume agora a editoria-geral da Rbem, é editora associada da Rbem há mais de uma década, o que nos garante que a Revista não sofrerá descontinuidade em sua evolução para o aumento de seu prestígio e internacionalização.

De minha parte, continuarei a colaborar como editor associado, acreditando que somos um poderoso instrumento para fortalecer a Educação Médica como campo científico e acadêmico, bem como apoiar as políticas de transformação do ensino médico em nosso país e a melhoria da oferta de cuidados de saúde para a nossa população. A todas as diretorias que me apoiaram e a este projeto ao longo desse período, meu agradecimento. Aos colegas que contribuíram como editores associados, revisores, autores, divulgadores, meu agradecimento por sua participação nesse projeto enquanto estive à frente dele. A Rozane Landskron, cuja atuação sempre foi indispensável ao "funcionamento das engrenagens da Revista" e no suporte afetivo, meu agradecimento especial, seguro de que sem o seu trabalho eu não teria conseguido permanecer tanto tempo à frente da Revista. Às nossas fundamentais bibliotecárias, cuja atuação também foi estratégica para a estruturação e editoração da Revista, meu agradecimento. E a Lilian Koifman, meu agradecimento por toda a sua colaboração ao longo desses anos e, em especial, por assumir a "criança" a partir de agora. 